\title{
PENGARUH EKSTRAKSI ZAT WARNA ALAM DAN FIKSASI TERHADAP KETAHANAN LUNTUR WARNA PADA KAIN BATIK KATUN
}

\author{
The Effect Extraction Method and Fixation of Natural Dyes to Color Fastness on Cotton Fabric
}

\author{
Titiek Pujilestari
}

Balai Besar Kerajinan dan Batik, Jl.Kusumanegara No.7 Yogyakarta, Indonesia

Telp.085249402277, E-mail: titiekpujilestari@yahoo.com

Tanggal Masuk: 25 Maret 2014

Tanggal Revisi: 16 Juni 2014

\begin{abstract}
ABSTRAK
Kain katun merupakan jenis kain yang terbuat dari serat kapas, mempunyai sifat mudah menyerap bahan alami maupun kimia dan banyak digunakan untuk bahan media batik. Telah dilakukan penelitian ekstraksi pada lima jenis zat warna alam dengan menggunakan air. Variasi antara bahan pembawa zat warna dengan air adalah $1: 6$ dan $1: 8$. Fiksasi dilakukan dengan menggunakan kapur, tunjung, tawas, campuran kapur dengan tetes dan tanpa fiksasi. Penelitian dilakukan untuk mengetahui pengaruh penambahan air pada ekstraksi dan bahan fiksasi terhadap ketahanan luntur warna pada kain. Hasil penelitian menunjukan bahwa ekstraksi zat warna alam dari daun indigo, daun mangga, kulit kayu nangka, kulit buah manggis dan biji buah kesumba dengan menggunakan air sebanyak 6 dan 8 bagian, memberikan hasil yang tidak jauh berbeda. Jenis zat warna alam dan bahan fiksasi yang diaplikasikan untuk pembatikan kain katun yang memberikan ketahanan luntur baik adalah : kulit buah manggis dengan fiksasi kapur, tawas dan tanpa fiksasi, biji buah kesumba/bixa dengan fiksasi tunjung dan tawas, kulit kayu nangka dengan fiksasi tunjung, daun mangga dengan fiksasi tawas. Daun indigo mempunyai ketahanan luntur warna yang baik sampai sangat baik terhadap pencucian, tetapi kurang baik sampai baik terhadap sinar terang hari. Penggunaan fiksasi campuran kapur dan tetes tebu menghasilkan ketahanan luntur warna pencucian dan sinar terang hari lebih rendah dibanding fiksasi dengan kapur. Ketahanan luntur dari kelima zat warna alam terhadap pencucian lebih baik dibanding ketahanan luntur terhadap sinar terang hari.
\end{abstract}

Kata kunci: zat warna alam, ekstraksi, fiksasi, katun

\begin{abstract}
The cotton fabric is a type of fabric made from cotton fiber, its easily absorbed material both natural and chemical, and widely used as a material for batik.Research extraction of five types of natural dyes made with a variety of colour materials carrier and the use of water is $1: 6$ and $1: 8$. Fixation of color on fabric using lime, lotus, alum, lime mixtures with mollases and without fixation drops as controls. The study aimed to determine the effect of the use of water in the extraction and fixation materials to color fastness on batik cloth. Ekstraksi of natural dyes from indigo leaves, mango leaves, bark jack fruits, mangosteen rind and fruit seeds kesumba (bixa) by using water as much as 6 and 8 sections, provide results that are not much different. Types of natural dyes and materials that applied for fixation batik cotton fabric that provides excellent fade resistance are : fixation mangosteen rind with lime, alum and without fixation, fruit seeds kesumba / Bixa with lotus fixation and alum, jack fruit bark with lotus fixation, fixation mango leaves with alum. Indigo leaves have good color fastness to washing, but less well against the bright light. The use of fixation mixture of lime and molasses produces washing color fastness and light the light of day is lower than fixation with lime. Fifth fastness of natural dyes to washing better fastness to light than the light of day
\end{abstract}

Keywords: natural dyes, extraction, fixation, cotton 


\section{PENDAHULUAN}

Indonesia merupakan negara yang kaya akan sumber alam hayati, terkenal dengan kekayaan keanekaragaman tumbuhtumbuhan yang mengandung berbagai macam zat warna. Zat warna alam merupakan hasil ekstraksi dari daun, batang, kulit, bunga, buah, akar tumbuhan dengan kadar dan jenis colouring matter bervariasi sesuai dengan spesiesnya (Murwati dkk, 2010). Colouring matter adalah substansi yang menentukan arah warna dari zat warna alam, merupakan senyawa organik yang terkandung didalam zat warna alam (Lestari, 2000).

Zat warna alam dapat diperoleh dengan berbagai cara sesuai sifat dari masingmasing bahan pembawa warna. Bahan pembawa warna ada yang dapat digunakan secara langsung, dan ada yang harus melalui ekstraksi maupun fermentasi terlebih dahulu sebelum digunakan. Cara ekstraksi untuk memperoleh gugus pembawa warna sangat bervariasi dan akan berpengaruh terhadap warna yang ditimbulkan. Zat warna alam yang diperoleh dari tumbuhan atau zat warna mordan merupakan zat warna yang dapat bersenyawa dengan oksida-oksida logam dengan membentuk senyawa berwarna yang tidak larut dalam air.

Proses ekstraksi pada semua bahan secara garis besar adalah sama yaitu mengambil pigmen atau zat warna yang terkandung dalam bahan. Perlakuan ekstraksi dengan cara pemanasan dengan merebus bahan pembawa zat warna alam menggunakan air adalah cara yang paling banyak dilakukan. Air yang ditambahkan untuk ekstraksi bahan pembawa warna jumlahnya tertentu dengan tujuan efisiensi dan untuk memperoleh ketuaan warna. Perebusan dilakukan hingga volume air menjadi setengahnya, apabila menghendaki larutan zat warna lebih kental, perebusan dapat dilanjutkan sehingga volume sisa perebusan menjadi sepertiga dari volume awal.

Untuk memperoleh zat warna yang mempunyai ketahanan luntur warna baik maka perlu dilakukan proses fiksasi zat warna. Fiksasi dapat berfungsi memperkuat warna dan merubah zat warna alam sesuai dengan jenis logam yang mengikatnya serta untuk mengunci zat warna yang telah masuk kedalam serat . Proses fiksasi pada prinsipnya adalah mengkondisikan zat pewarna yang telah terserap dalam waktu tertentu agar terjadi reaksi antara bahan yang diwarnai, dengan zat warna dan bahan yang digunakan untuk fiksasi. Bahan yang biasa digunakan untuk fiksasi adalah tawas $\left[\mathrm{K}_{2} \mathrm{SO}_{4} \cdot \mathrm{Al}_{2}\left(\mathrm{SO}_{4}\right)_{3} \cdot 24 \mathrm{H}_{2} \mathrm{O}\right]$, kapur $\left(\mathrm{CaCO}_{3}\right)$ dan tunjung $\left(\mathrm{FeSO}_{4}\right)$.

Sebagai media pada proses pembatikan digunakan kain katun, yang mempunyai warna kapas sedikit krem dan struktur kimianya merupakan senyawa benzena yang mengandung gugus hidroksil yang mudah menyerap air, sebagian besar terdiri dari selulosa (komponen utama), lemak, malam dan pektin. Kekuatan serat kapas dipengaruhi oleh kadar selulose dalam serat (Suheryanto, 2013).

Penelitian ini bertujuan untuk mengetahui pengaruh perbandingan air yang ditambahkan pada ekstraksi zat warna alam dan aplikasi pewarnaan pada kain katun dengan beberapa variasi jenis fiksasi. Dengan penelitian ini diharapkan dapat diketahui perbandingan penggunaan air yang optimum, jenis zat pemfiksasi untuk mendapatkan warna yang baik dan mempunyai ketahanan luntur.

\section{METODE PENELITIAN}

\section{Bahan dan Peralatan}

Bahan yang digunakan pada penelitian adalah lima jenis tanaman yaitu daun indigo 
(Indigofera tinctoria), daun mangga (Mangifera indica), kulit kayu nangka (Artocarpus heterophillya), kulit buah manggis (Gabcinia mangostana L.), biji buah kesumba/bixa (Bixa orellana). Tanaman diperoleh di pekarangan di daerah Yogyakarta, daun indigo diperoleh di daerah pantai di Kabupaten Kulon Progo. Beberapa bahan pembantu untuk fiksasi yaitu tawas, tunjung, kapur dan tetes tebu; kain katun sebagai bahan untuk uji pewarnaan, gas elpiji sebagai sumber energi.

Peralatan yang digunakan meliputi bak tempat pewarnaan, neraca, termometer, panci, saringan, pengaduk, kompor serta beberapa peralatan untuk keperluan pengujian.

\section{Pelaksanaan Penelitian}

\section{Ekstraksi Zat Warna Alam}

Penelitian menggunakan lima jenis tanaman meliputi daun indigo, daun mangga, kulit kayu nangka, kulit buah manggis dan biji buah kesumba (bixa). Masing-masing bahan dipilih yang baik, tidak busuk dan tidak berjamur. Untuk bahan kayu perlu pengecilan ukuran dan menggunakan alat crusher sedangkan bahan berupa daun yang masih basah selain daun indigo dipotong-potong kecil.

Untuk ekstraksi setiap 1 (satu) $\mathrm{kg}$ bahan baku zat warna alam ditambahkan air sebanyak 6 liter untuk perbandingan $1: 6$ dan 8 liter untuk perbandingan $1: 8$. Bahan pembawa warna dan air dimasukkan kedalam panci perebusan dan dipanaskan hingga mendidih sampai air rebusan tersisa setengahnya (50\% dari volume air awal).

Untuk biji kesumba (bixa) pengambilan warna secara langsung yaitu biji kesumba dipisahkan dari kelopaknya kemudian ditimbang dan diremas-remas selanjutnya ditambahkan air sesuai perlakuan dan disaring.
Ekstraksi terhadap daun indigo dilakukan dengan cara fermentasi, daun indigo ditimbang dan ditambahkan air sesuai perlakuan dan dibiarkan selama 24 jam. Daun dipisahkan dengan cara penyaringan kemudian ditambahkan larutan air kapur $40 \mathrm{~g} / \mathrm{l}$ dan campuran dibiarkan selama 12 jam. Lapisan bagian atas yang berwarna kuning dibuang dan lapisan bawah yang berwarna biru diambil sebagai zat warna alam indigo.

\section{Pencelupan Kain Katun Dengan Zat Warna Alam}

Kain katun dengan ukuran 2 meter dimordan menggunakan larutan tawas $40 \mathrm{~g} / \mathrm{l}$ kemudian dikeringkan tanpa diperas.

Kain katun dibatik dan dicelup dalam zat warna alam masing-masing dua kali celupan dan dikeringkan. Pembatikan (tutup/ tembok) disesuaikan dengan motif yang dikehendaki, dicelup lagi, dikeringkan dan difiksasi dengan larutan tawas, tunjung, kapur dan campuran larutan kapur dan tetes. Kain dicuci hingga bersih kemudian dilorod dengan pemanasan dan ditambahkan pati kanji didalamnya.

Kain dicuci kembali dan dikeringkan, sehingga menghasilkan kain batik katun zat warna alam.

\section{Pengujian}

Kain batik katun yang dihasilkan kemudian dilakukan pengujian ketahanan luntur warna terhadap pencucian $40{ }^{\circ} \mathrm{C}$ dan ketahanan luntur warna terhadap sinar terang hari. Metoda pengujian mengacu pada SNI ISO 105 - C 06 - 2010 dan SNI ISO 105 - B01 : 2010.

\section{HASIL DAN PEMBAHASAN}

Ekstraksi lima jenis zat warna alam yaitu daun indigo, daun mangga, kayu kulit nangka, kulit buah manggis dan biji buah 
kesumba menggunakan perbandingan penambahan air 1 ; 6 dan 1 : 8 kemudian dilakukan pewarnaan terhadap katun dengan cara pembatikan. Mordan akhir dilakukan dengan lima perlakuan fiksasi masingmasing tanpa fiksasi, fiksasi dengan kapur, dengan tunjung, tawas dan campuran kapur + tetes. Pengujian dilakukan terhadap ketahanan luntur warna terhadap pencucian $40{ }^{\circ} \mathrm{C}$ dan ketahanan luntur warna terhadap sinar terang hari. Hasil pengujian disajikan seperti pada Tabel 1, 2, 3, 4 dan Tabel 5 .

Hasil pengujian pada Tabel 1 ketahanan luntur warna terhadap pencucian pada kain katun dengan pembatikan tanpa fiksasi ratarata memberikan nilai baik dengan skor 4 (empat). Perlakuan ekstraksi dengan perbandingan 1 : 6 dan 1 : 8 mempunyai ketahanan luntur warna terhadap sinar terang hari rata-rata cukup baik sampai baik. Pada zat warna kulit buah manggis dengan semua perlakuan ekstraksi masih memberikan ketahanan luntur warna terhadap pencucian dan sinar terang yang baik dengan nilai 4 dan sangat baik nilai 4 5. Kekuatan serat kapas dipengaruhi oleh kadar selulosa dalam serat kain katun yang mampu menyerap zat warna alam, sehingga pada kain katun tanpa perlakuan fiksasi mampu mengikat warna dengan baik sehingga tahan dalam pencucian dan sinar terang hari. Hal ini sesuai dengan pendapat Suheryanto (2013) bahwa serat kapas struktur kimianya merupakan senyawa benzena yang mengandung gugus hidroksil yang mudah menyerap air yang sebagian besar terdiri dari selulose (komponen utama), lemak, malam dan pektin.

Tabel 1. Hasil Rerata Ketahanan Luntur Warna Kain Katun Tanpa Fiksasi

\begin{tabular}{|llcccc|}
\hline No. Jenis Zat Warna Alam & $\begin{array}{c}\text { Ketahanan Luntur Warna } \\
\text { Terhadap Pencucian } \mathbf{4 0}{ }^{\mathbf{0}} \mathbf{C}\end{array}$ & $\begin{array}{c}\text { Ketahanan Luntur Warna } \\
\text { Terhadap } \\
\text { Sari }\end{array}$ & $\begin{array}{c}\text { Sinar: } \\
\text { Terang }\end{array}$ \\
\hline $\mathbf{1}$ & Daun Indigo & $1: 6$ & $1: 8$ & $1: 6$ & $1: 8$ \\
\hline $\mathbf{2}$ & Daun Mangga & 4 & $4-5$ & $3-4$ & $3-4$ \\
\hline $\mathbf{3}$ & Kulit Kayu Nangka & 4 & 4 & 4 & $3-4$ \\
\hline $\mathbf{4}$ & Kulit Buah Manggis & 4 & $3-4$ & $3-4$ & $3-4$ \\
\hline $\mathbf{5}$ & Biji Buah Kesumba (Bixa) & 4 & 4 & $4-5$ & 4 \\
\hline
\end{tabular}

Keterangan : Nilai 2 = Kurang baik, Nilai 3 = Cukup baik, Nilai 4 = Baik, Nilai 5 = Sangat baik.

Tabel 2 : Hasil Rerata Ketahanan Luntur Warna Kain Katun Dengan Fiksasi Kapur

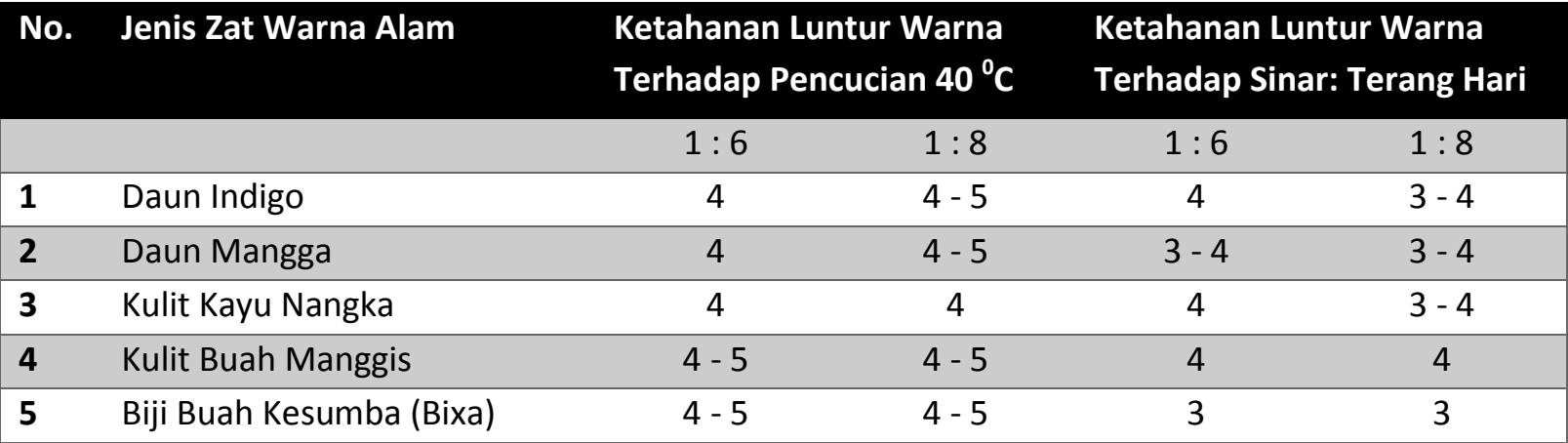

Keterangan : Nilai 2 = Kurang baik, Nilai 3 = Cukup baik, Nilai 4 = Baik, Nilai 5 = Sangat baik. 
Ketahanan luntur warna terhadap pencucian $40{ }^{\circ} \mathrm{C}$ kain batik katun dengan perlakuan fiksasi menggunakan kapur menunjukkan nilai 4 (baik) sampai nilai 5 (sangat baik). Selanjutnya ketahanan luntur warna terhadap sinar terang hari memberikan hasil yang bervariasi nilai 3 (cukup baik) sampai nilai 4 (baik). Hasil pengujian terlihat bahwa ketahanan luntur warna terhadap pencucian dengan perlakuan ekstraksi tidak menunjukkan perbedaan pada kelima zat warna alam, dan ketahanan luntur warna akibat pencucian lebih baik dibanding dengan ketahanan luntur warna terhadap sinar terang hari. Kulit buah manggis mempunyai ketahanan luntur warna paling baik dengan fiksasi kapur. Kulit buah manggis mengandung polifenol, termasuk xanthonen dan tanin. Perlakuan fiksasi dengan kapur dapat mengakibatkan meningkatnya daya serap kain katun terhadap zat warna alam dan untuk mengunci zat warna yang masuk kedalam serat.

Perlakuan ekstraksi menggunakan perbandingan jumlah air dan bahan pewarna memberikan hasil ketahanan warna kain katun setelah pencelupan yang berbeda beda tergantung bahan pewarna yang diekstrak.
Zat warna daun indigo menghasilkan ketahanan warna terhadap pencucian yang baik sampai sangat baik, tetapi kurang baik terhadap sinar terang hari. Daun mangga, kulit kayu nangka dan kulit buah manggis rata-rata cukup baik sampai baik dan paling baik pada biji buah kesumba mempunyai ketahanan warna baik sampai sangat baik. Menurut Rita (2010) dalam Triani dkk (2012) dikatakan bahwa untuk pewarnaan tekstil dan batik dapat menggunakan bagian tumbuhan kesumba yaitu kulit, biji buah kesumba dari bagian senyawa polarnya yaitu norbixin. Senyawa bixin dan norbixin mempunyai sifat kelarutan berbeda yaitu bixin tidak dapat larut dalam air dan norbixin larut dalam air dan keduanya merupakan golongan pigmen karotenoid.

Penggunaan fiksasi tawas pada pembatikan kain katun, dengan ekstraksi menggunakan air $1: 6$ dan $1: 8$ pada kelima jenis bahan pembawa warna memberikan hasil ketahanan luntur warna terhadap pencucian $40{ }^{\circ} \mathrm{C}$ dengan nilai 4 (baik) dan nilai 5 (sangat baik). Hasil ketahanan luntur warna terhadap sinar terang hari pada daun indigo dan kayu nangka memberikan nilai 3 (cukup baik).

Tabel 3 : Hasil Rerata Ketahanan Luntur Warna Kain katun Dengan Fiksasi Tunjung

\begin{tabular}{|llcccc|} 
No. & Jenis Zat Warna Alam & \multicolumn{2}{c|}{$\begin{array}{l}\text { Ketahanan Luntur Warna } \\
\text { Terhadap Pencucian } \mathbf{4 0}{ }^{\mathbf{0}} \mathbf{C}\end{array}$} & $\begin{array}{c}\text { Ketahanan Luntur Warna } \\
\text { Terhadap Sinar: Terang Hari }\end{array}$ \\
\hline & & $1: 6$ & $1: 8$ & $1: 6$ & $1: 8$ \\
\hline $\mathbf{1}$ & Daun Indigo & $4-5$ & 5 & 4 & $2-3$ \\
\hline $\mathbf{2}$ & Daun Mangga & $3-4$ & $4-5$ & 4 & $3-4$ \\
\hline $\mathbf{3}$ & Kulit Kayu Nangka & 4 & 4 & 4 & 4 \\
\hline $\mathbf{4}$ & Kulit Buah Manggis & $3-4$ & 4 & 4 & 4 \\
\hline $\mathbf{5}$ & Biji Buah Kesumba (Bixa) & 4 & $4-5$ & 4 & 4 \\
\hline
\end{tabular}

Keterangan : Nilai 2 = Kurang baik, Nilai 3 = Cukup baik, Nilai 4 = Baik, Nilai 5 = Sangat baik. 
Tabel 4 : Hasil Rerata Ketahanan Luntur Warna Kain katun Dengan Fiksasi Tawas

\begin{tabular}{|llcccc|}
\hline No. Jenis Zat Warna Alam & \multicolumn{2}{c|}{$\begin{array}{c}\text { Ketahanan Luntur Warna } \\
\text { Terhadap Pencucian }\end{array}$} & $\mathbf{4 0} \mathbf{~}^{\mathbf{C}}$ & $\begin{array}{c}\text { Ketahanan Luntur Warna } \\
\text { Terhadap Sinar: Terang Hari }\end{array}$ \\
\hline $\mathbf{1}$ & Daun Indigo & $1: 6$ & $1: 8$ & $1: 6$ & $1: 8$ \\
\hline $\mathbf{2}$ & Daun Mangga & 4 & 4 & 4 & 3 \\
\hline $\mathbf{3}$ & Kulit Kayu Nangka & $4-5$ & 5 & 4 & 4 \\
\hline $\mathbf{4}$ & Kulit Buah Manggis & $4-5$ & 4 & $3-4$ & $3-4$ \\
\hline $\mathbf{5}$ & Biji Buah Kesumba (Bixa) & 4 & 5 & $4-5$ & 4 \\
\hline
\end{tabular}

Keterangan : Nilai $2=$ Kurang baik, Nilai $3=$ Cukup baik, Nilai $4=$ Baik, Nilai $5=$ Sangat baik.

Tabel 5 : Hasil Rerata Ketahanan Luntur Warna Kain katun Dengan Fiksasi Kapur dan Tetes

\begin{tabular}{|llcccc|}
\hline No. Jenis Zat Warna Alam & \multicolumn{2}{c}{$\begin{array}{c}\text { Ketahanan Luntur Warna } \\
\text { Terhadap Pencucian }\end{array}$} & $\mathbf{4 0}{ }^{\mathbf{C}} \mathbf{C}$ & $\begin{array}{c}\text { Ketahanan Luntur Warna } \\
\text { Terhadap Sinar: Terang Hari }\end{array}$ & $1: 8$ \\
\hline $\mathbf{1}$ & Daun Indigo & $1: 6$ & $1: 8$ & $1: 6$ & 3 \\
\hline $\mathbf{2}$ & Daun Mangga & 4 & 4 & 4 & 4 \\
\hline $\mathbf{3}$ & Kulit Kayu Nangka & 4 & $3-4$ & $4-5$ & $3-4$ \\
\hline $\mathbf{4}$ & Kulit Buah Manggis & $3-4$ & 4 & $4-5$ & $4-5$ \\
\hline $\mathbf{5}$ & Biji Buah Kesumba (Bixa) & 4 & $4-5$ & 3 & 4 \\
\hline
\end{tabular}

Keterangan : Nilai 2 = Kurang baik, Nilai 3 = Cukup baik, Nilai 4 = Baik, Nilai 5 = Sangat baik.

Hasil pengujian seperti Tabel 5 menunjukkan bahwa penggunaan campuran fiksasi kapur dan tetes tebu ternyata ketahanan luntur warna terhadap pencucian mengalami penurunan dibanding penggunaan fiksasi dengan kapur. Zat warna kulit buah manggis dan daun mangga paling baik terhadap ketahanan luntur warna sinar terang hari. Dari perlakuan fiksasi dengan campuran kapur dan tetes tebu, pada semua bahan zat warna alam mempunyai nilai 3 (cukup baik). Hal ini berarti penggunaan fiksasi campuran kapur dan tetes tebu kurang memberikan hasil yang diharapkan yaitu pada penggunaan perbandingan $1: 6$ dan $1: 8$ pada daun indigo, daun mangga, kulit kayu nangka, kulit buah manggis dan biji buah kesumba.
Kelima jenis zat warna alam mempunyai arah warna yang berbeda dan perlakuan fiksasi dapat mempengaruhi arah warna menjadi berbeda dengan warna tanpa perlakuan fiksasi. Secara organoleptik warna dari masing-masing bahan sebelum fiksasi adalah daun indigo memberikan warna biru, daun mangga warna kuning kehijauan, kayu kulit nangka kearah warna kuning, kulit buah manggis memberikan warna ungu tua dan biji buah kesumba (bixa) memberikan warna oranye. Hasil pencelupan kelima jenis ekstrak zat warna alam dengan perbandingan $1: 6$ dan $1: 8$ dan perlakuan fiksasi seperti pada Gambar 1, 2, 3, 4 dan Gambar 5. 


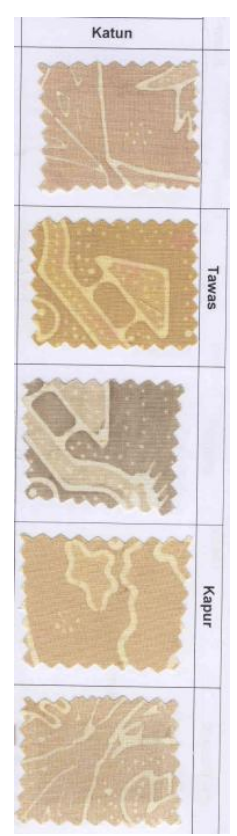

(a)

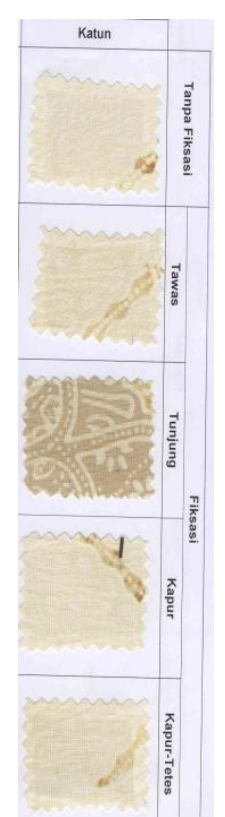

(b)
Gambar 1. Katalog arah warna ekstraksi kayu nangka (a) 1:6, (b) 1:8

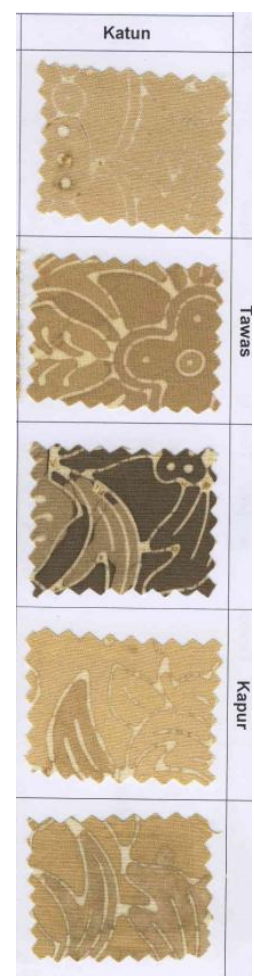

(a)

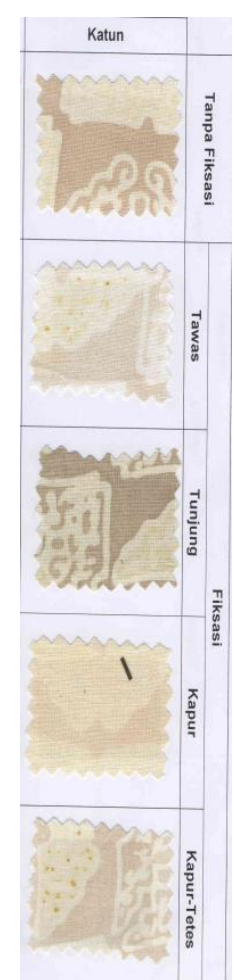

(b)
Gambar 2. Katalog arah warna ekstraksi daun mangga (a) 1:6, (b) 1:8

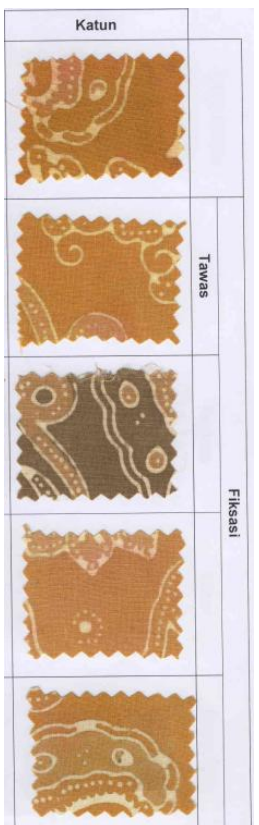

(a)

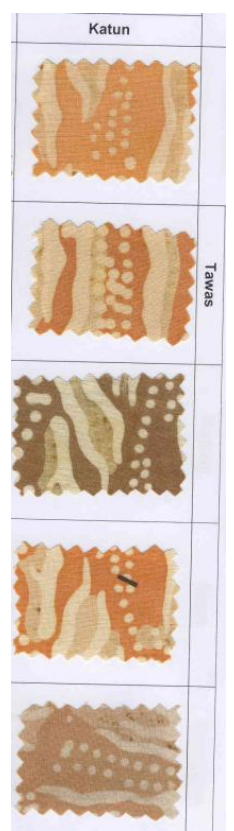

(b)
Gambar 3. Katalog arah warna ekstraksi biji buah bixa (a) 1:6, (b) 1:8

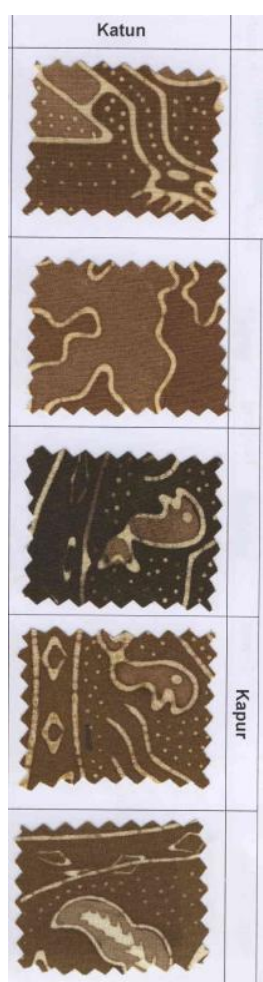

(a)

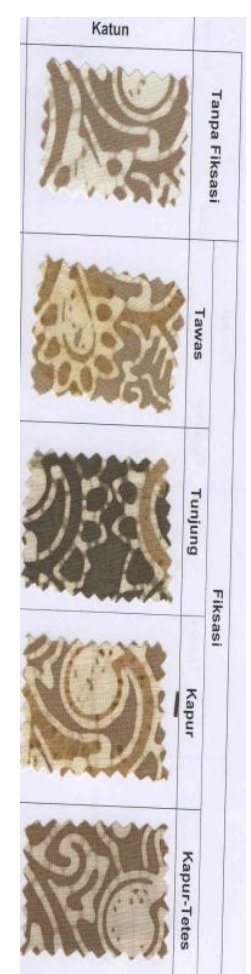

(b)
Gambar 4. Katalog arah warna ekstraksi kulit buah manggis (a) 1:6, (b) 1:8 


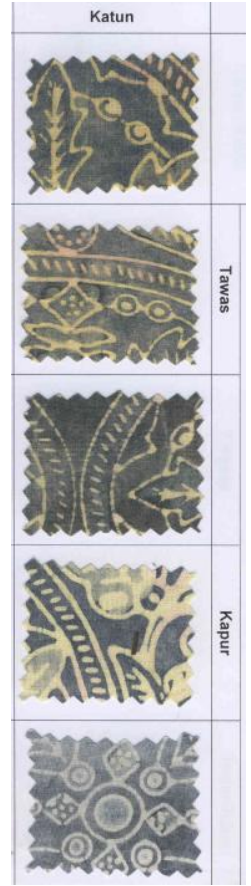

(a)

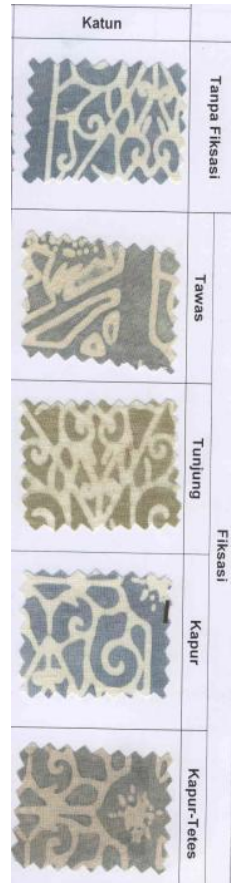

(b)
Gambar 5. Katalog arah warna fermentasi daun Indigo (a) 1:6, (b) 1:8

\section{KESIMPULAN DAN SARAN Kesimpulan}

Ekstraksi zat warna alam dengan perbandingan $1: 6$ dan $1: 8$ menghasilkan zat warna yang dapat diaplikasikan pada pembatikan kain katun dan memberikan hasil yang tidak jauh berbeda.

Perlakuan yang memberikan ketahanan luntur baik adalah: kulit buah manggis dengan fiksasi kapur, tawas dan tanpa fiksasi, biji buah kesumba/bixa dengan fiksasi tunjung dan tawas, kulit kayu nangka dengan fiksasi tunjung, daun mangga dengan fiksasi tawas. Daun indigo mempunyai ketahanan luntur warna yang baik sampai sangat baik terhadap pencucian, tetapi kurang baik sampai baik terhadap sinar terang hari. Penggunaan fiksasi campuran kapur dan tetes tebu menghasilkan ketahanan luntur warna pencucian dan sinar terang hari lebih rendah dibanding fiksasi dengan kapur.

\section{Saran}

Kain batik katun tidak dijemur pada terang hari.

\section{DAFTAR PUSTAKA}

Suheryanto, D. 2013. Eksplorasi Pembuatan Zat Warna Alam dalam Bentuk Pasta dengan Teknik Evaporasi. Yogyakarta: Balai Besar Kerajinan dan Batik, Badan Pengkajian Kebijakan Iklim dan Mutu Industri, Kementerian Perindustrian.

Lestari, K.W.F. dan H. Suprapto. 2000. Natural Dyes In Indonesia. Yogyakarta: Balai Besar Penelitian dan Pengembangan Industri Kerajinan dan Batik.

Murwati, E.S. dkk. 2010. Penelitian Teknik Pewarnaan Enceng Gondok, Agel, Pandan dan Purun dengan Zat Warna Alam. Laporan Penelitian. Balai Besar Kerajinan dan Batik. Yogyakarta: Badan Penelitian dan Pengembangan Industri, Kementerian Perindustrian.

Badan Standardisasi Nasional, 2010. SNI ISO 105 - C06 : 2010. Tekstil- Cara Uji Tahan Luntur Warna - Bagian C06: Tahan Luntur Warna Terhadap Pencucian Rumah Tangga dan Komersial. Jakarta: BSN.

Badan Standardisasi Nasional, 2010. SNI ISO 105 - B01: 2010. Tekstil- Cara

Uji Tahan Luntur Warna - Bagian B01: Tahan Luntur Warna terhadap Sinar, Sinar Terang Hari. Jakarta: BSN.

Triani, A., Catherine T.J., Jakariya N., dan Bayu, K.M. 2012. Pencarian Hasil Pencelupan Optimum dari Ekstrak Biji Buah Tanaman Kesumba pada Kain Kapas, Sutera, Poliamida, dengan Variasi Penambahan Zat Pembantu dan Proses Fiksasi. 
(http://potretnugraha.wordpress.com /download/pencarian-hasil-celupoptimal-dari-zat-warna-ekstrak-bijibuah-kesumba-pada-kain-kapas- sutera-dan-nilon-dengan-berbagaivariasi-zat-pembantu-juga-prosesfiksasi-2/, diakses 19 Maret 2014). 
40 | Dinamika Kerajinan dan Batik, Vol. 31 , No. 1, Juni 2014 